\title{
Correlative Study
}

National Cancer Institute

\section{Source}

National Cancer Institute. Correlative Study. NCI Thesaurus. Code C16100.

A type of study that tests for a relationship between a condition and a potential causal factor of the condition. 